DOI 10.18551/rjoas.2019-04.10

\title{
RURAL HIERARCHY OF PROSPERITY: LIVELIHOOD DIVERSIFICATION AND ITS IMPLICATIONS ON RURALITY
}

\author{
Pujiriyani Dwi Wulan* \\ National Land College, Yogyakarta, Indonesia
}

Soetarto Endriatmo

Faculty of Human Ecology, Bogor Agricultural University, Bogor, Indonesia

Santosa Dwi Andreas

Faculty of Agriculture, Bogor Agricultural University, Bogor, Indonesia

Agusta Ivanovich

Faculty of Human Ecology, Bogor Agricultural University, Bogor, Indonesia

*E-mail: lucia wulan@yahoo.com

\begin{abstract}
This study aimed to analyze the social changes in rural areas as a consequence of the shift of peasants to non-agrarian activities. Social change in the context of this paper is associated with livelihood diversification and its implications for rural restratification and its characteristic today. The research is conducted using qualitative method through community case study approach. Data collection is obtained through direct observation, face-to-face interviews and personal history. Respective perspective from three generations is used to track community history and changes that occur in the context of the village, community, and agricultural activities. The result shows that economic diversification has created a new rurality. New rurality or present-day rural characteristic are indicated by increasing prosperity, and agriculture that is no longer the dominant source of income. Livelihood diversification provides opportunities for vertical social mobility for the rural poors which are the offsprings of farm laborers and tenants who choose to become migrant workers in Korea. There has been a restratification characterized by the emergence of migrant groups as a new social class that shifts the upper class position previously occupied by landlords and their descendants. They are a new upper class in social stratification in the rural that manages to show their prosperity through the accumulation of capital from remittances they brought back to the village.
\end{abstract}

\section{KEY WORDS}

Indonesia, migrants, landlords, restratification, social class, social change.

Diversification of livelihoods away from agriculture occurs extensively in rural areas. People in the rural who depend on agriculture for their livelihoods are dwindling. The declining land resources, stagnant agricultural production prices and the increasing needs of farm households are some of the reasons thatledpeasants no longer rely solely on agriculture to meet their needs. Peasants require non-farm activities to stabilize and maintain the sustainability of their livelihoods (Rigg, 2001; Steward, 2007). Peasants are even will be completely disappeared from the rural sector if there is absolutely no alternative source of income outside agriculture (Chase, 2010). Only those who have adequate agricultural land, external resources and abundant labors can earn greater revenues from non-farm income. Peasants with limited land must have jobs outside the non-agricultural sector to survive.

Diversification opens opportunities for vertical social mobility for the rural poors. The poors who have no land nor power capital can earn income outside the agriculture while the possibility to obtain jobs through education and skills becomes more opened. Nonagricultural activities are increasingly seen as a way out to prosperity in the rural. Bryceson's 
research in South Africa (2002), shows that those who have only limited (narrow) land with poor quality (unproductive) finally choose to do trading as a source of livelihood. Despite opening up opportunities for social mobility, diversification can also further strengthen social stratification. This is related to the greater income earned by the elite group due to the transfer of agricultural capital to more favorable nonfarm activities. Non-agricultural activities provide a path to prosperity.

Diversification becomes a part of territorial change in the rural area that turns the village into its new face. Most villagers have revenues which are not related to agriculture. This situation then encourages the stagnation of sources of income from agriculture. Agriculture has grown as a tertiary sector and is no longer a primary sector or what Bryceson (1996) called with the term deagrarianization. Deagrarianization does not indicate that agriculture disappears. Deagrarianization emphasizes the growing importance of various sources of income outside agriculture (Yaro, 2006; Terano and Fujimoto, 2009; Connor and Mtwana, 2017; Pritchard et al 2017; Hebinck, 2018; Shackelton, 2018;). Agrarian life is declined as impact from its farming communities that no longer fully make agriculture as the livelihood base.

Research on livelihood diversification and the decline of rural agriculture activities has been widely conducted (Bryceson, 2002; Meert et al., 2005, Steward, 2007; Ducrotoy et al., 2017; Khan, et al., 2017; Ebenezer, M and Abbyssinia, M, 2018 ). In this case, most studies focusing on the effect of non-farm income as a strategy to reduce the risk of peasants' limited income from their agricultural activities. No studies have specifically focused on the influence of livelihood diversification on social stratification changes in rural areas. This paper will discuss deepeer about the social changes that occur in rural areas as a consequence of the shift of peasants to non-agrarian activities. How does livelihood diversification affect the present-day rural characteristic? How does diversification create restratification in the rural? And how is the prosperity represented by each class in the rural hierarchy?

\section{METHOD OF RESEARCH}

Data for this paper were obtained using a community case study approach. This approach chosen for obtaining detailed and rich data (Berg, 2001; Creswell, 2003, and Yin, 2003). The community in this research is the Dukuh Jongso (Jongso Hamlet)peasants community, one of the communities that have the uniqueness as a modern peasant community but also still maintain the traditional order. This community represents the full character of a rapidly growing community of peasant with a variety of non-agricultural livelihood sources and increased prosperity due to remittances sent from Korea. However, the other character of this peasant community is they remain attached to the traditional order through the social stratification inherited by the landlord class in the past to the descendants to this day.

The data collection for this paper is obtained through direct observation, face-to-face interviews and personal histories. The perspectives of three different generations (grandparents- as first generation; father/mother- as second generation; and children as thirdgeneration) used to obtain a community history and description of rural change over the last twenty years, particularly regarding to the shifting of agricultural activity to nonagricultural and hierarchical or social stratification change that occurs along with it. Archival records in the form of maps and lists of taxpayers are also used in this study to obtain detailed descriptions of the village landscape as well as the mapping of the stratificationupon land ownership.

\section{RESULTS AND DISCUSSION}

Jongso community is one of the rice farming communities in Wotan Village, Sukolilo District, Pati Regency, Central Java, Indonesia. Wotan Village is the largest food supplier in Pati Regency and also the village that has the largest rice field in Indonesia for the size of the village (1723 hectares). Wotan village is also known as a wealthy (sugih) village with a more 
advanced development than the surrounding villages. It has flat landscapes with vast expanses of rice fields dominate the region. Paddy rice is a major agricultural commodity with an average production of 3.5 tons per hectare and a total production amount of 5400 tons of the entire land that can be harvested.

Jongso's hamlet located at the very end (north side) of Wotan Village. This hamlet is known as the richest in Sukolilo district because this is where the landlord and his family (pioneers) that owns large lands settled. The tenants of these landlords even have a land area up to 25 hectares per person. These pioneers are the migrants from Undaan District, Kudus. Until now, the history of this vast land ownership can still be found. The structure of land ownership at the village level shows that there are 1\% (101 people) people owning land above 1 hectares (ha) as can be seen in Figure 1. Out of this amount, about $50 \%$ (68 owners of large land) are in Wotan Hamlet and Jongso Hamlet.

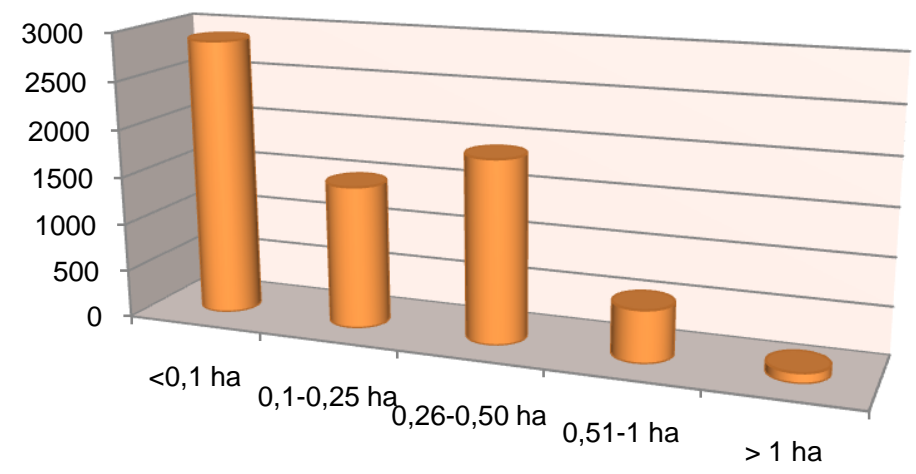

Figure 1 - Structure of land ownership in Wotan Village (Source: adapted from DKHP PBB Wotan Village, Sukolilo, Pati, 2018)

Present days Jongso is different from Jongso in the past. Jongso is now better known as the 'kampung TKl' means 'migrant hamlet'. The first generation of Jongso Hamlet migrants began in the 90's for work overseas. South Korea is a favorable country as the main destination for their departure in addition to Japan and Taiwan. The people in Jongso are even more facilitated because there is a Korean language school built in this village, so it does not have to go far out of the village to prepare their departure. If they have passed the Korean language, it is certain they will soon be dispatched. Currently there are 76 young people who are still living in South Korea with a five year contract system and about 40 people who have completed the contract and settled back in this village. Diversification becomes a part of territorial change in the rural that turns the village into its new face (Bryceson, 1996; Chase, 2010). The earliest form of economic diversification in Jongso was by raising buffalo. Meanwhile, the most developed and popular diversification today is with the industry-scale chicken farming business as can be observed in Figure 2.

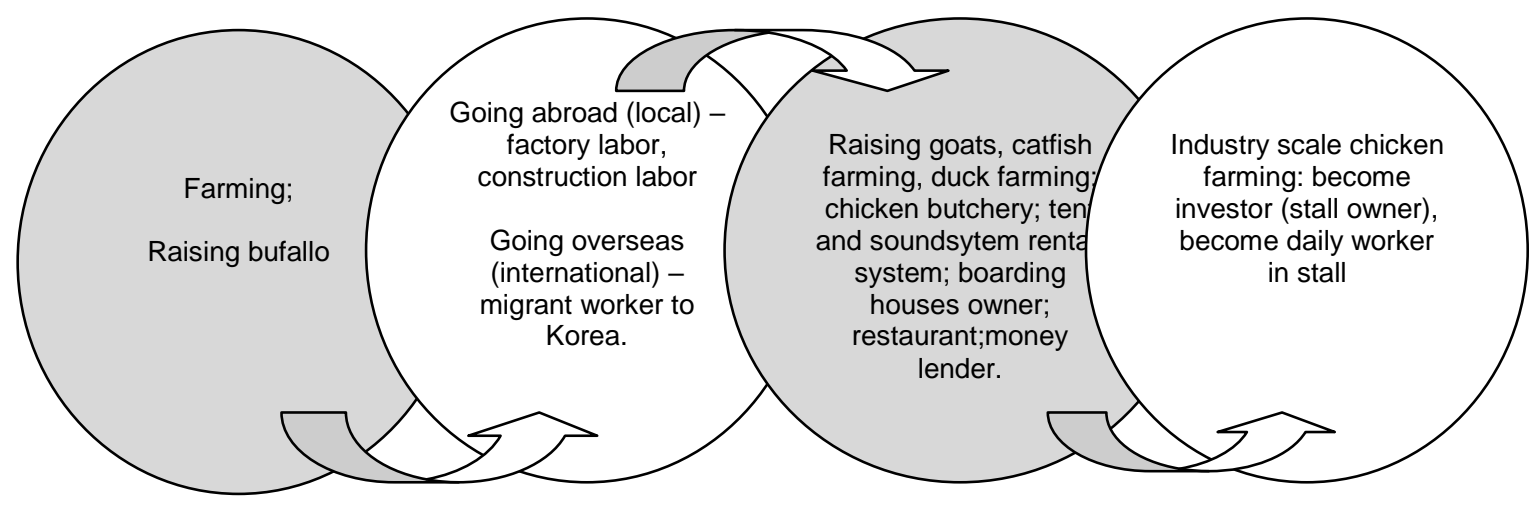

Figure 2 - Economics Diversification in Jongso Hamlet (processed from primary data, 2018) 
Departing to Korea becomes a job trend that is considered to bring prosperity faster. The departure of Jongso citizens to Korea became the starting point of change experienced by people in this region. New job opportunities outside agriculture are beginning to open. New businesses such as money lending services, chicken butchery, duck farming, catfish farming, tents and soundsystems rental, boarding houses and restaurants can be found around the village. One growing business is chicken farming industry with a turnover of billions of rupiahs. The farm, which has been built since 2015 , originally was a government empowerment program (BNP2TKI) aimed at 'retired TKI' (former migrant workers) in order not to return to be migrant workers. Peasants who are interested to participate must have a capital of $40 \%-60 \%$ or around $500-700$ million rupiah. The operational value for making a cage per population of chicken is 50 thousand rupiah. For a cage with a capacity of 30,000 chicken, it takes about 1.5 billion rupiah. Owner earnings can reach 50 million in one time harvest season. Rural is no longer identified with poverty. The new rurality in Jongso as a whole is evident from the village heterogeneity due to economic changes and landscape changes. In this case migrants as mentioned by Kaitlin \& Mary (2010) are considered to have the greatest financial capacity so that when they return home, they usually show their economic superiority.

The hierarchical distinction of society into social classes (social stratification) has been recognized by the Jongso community from the very beginning of this hamlet to the present day. Public awareness of the class is manifested in the term 'wong sugih' (upper class) and 'wong ora duwe' (lower class). Historically, the two classes are geographically separated in two kampongs namely 'Kampung Kulon' (for the upper class) and 'Kampung Wetan' (for the lower classes). Kampung Kulon is occupied by pioneers with its specific type of limasan-roof shaped houses. They are known as people who have dozens or even hundreds of acres of land. If Kampung Kulon known as the village of the king of the land, Kampung Wetan or Kampung Tanggulan is a village inhabited by workers from the village pioneers. They are the middle to lower class. They used to live in one big house together. They then have offspring and thrive to become what they are today. Their daily activity is to keep hundreds of buffaloes belonging to the landlords and to do the various jobs requested by the landlords. These workers have high loyalty to their patrons. This loyalty is shown by 'bekti' (filial) and 'manut' (submissive) on the command of the landlord.

The social hierarchy at Jongso was also born due to the ownership of agrarian resources (land) which ultimately determines the position within the existing social hierarchy. Wong sugih is in an upper position because it has a large land while the workers/tenants are in the lower class position because they have no land (landless). The decline of agricultural dominance in the rural economic structure has led to changes in social structure. The hierarchy of prosperity in the rural has also changed. To improve living standards, communities have an increasingly diverse sources of income. As mentioned in Halamska (2011), restratification takes place since rural populations have begun to be dettached of agriculture.

In the context of Jongso, social class changes have been felt since the return of former Indonesian migrant workers who eventually became economically successful people. This change began to occur in the 1990s. The position of the landlord who had been a top class in the rural, was replaced by the new rich people who returned from Korea. This former generation of migrant workers now appears as a respected new class. Former Korean migrant workers are known to have high buying power. They are able to raise the price of land in this region. Currently (2018) the price of land has reached 125-135 million per square (1/7 hectare). From the history of buying and selling that once existed in Jongso, a former Korean migrant can buy land up to 6 squares at a price of $\mathrm{Rp} .85$ million per square or a total of 510 million. These lands were bought from Jongso people who sold the land, some of them landlords who needed money to pay for their children's college. There is a tendency in Jongso that those who continue their education until college are the children of the old rich (landlords). No one of the children of this landlord becomes a TKI. They choose formal employment paths in government or private offices. Those who leave for Korea are usually children from the lower class with average education of junior or senior high school 
graduates. The success of former Korean migrants becomes them as a class of rich people with characteristics different from the characteristics of the rich or the upper class coming from the landlords as can be seen in Figure 3.

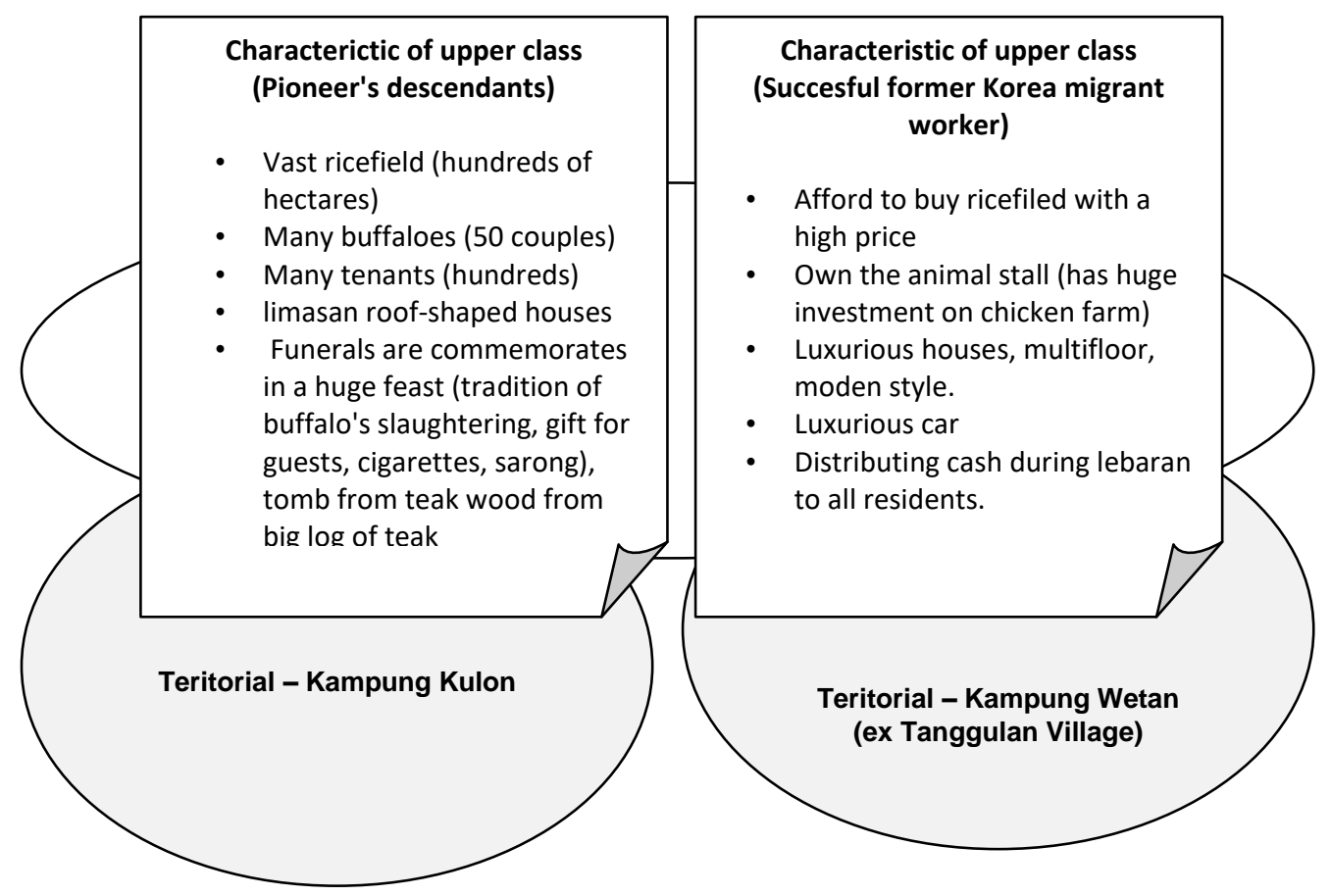

Figure 3 - Characterictic of pioneers's upper class descendants and class of formerly succeed migrant worker from Korea (primary data, 2018)

They become upper class (new rich people) not because they have vast ricefields or become descendants of first settlers but because it can show its success by buying rice field, a chicken stall with billions of investments, building a magnificent mansion-style houses, buying luxury cars and handing out money during Eid.

Former Korean migrant who is in a low-class citizen has a position that is respected even more than the landlord because it is considered to have a more egalitarian pattern of communication, flexible, not dictatorial and open-minded. Meanwhile, landlords are usually respected in their internal environment (their clients). The former migrant worker who became the new rich class is not involved in the formal leadership of the village so that it is considered more objective and able to balance the decision that has been dominated by the upper class that has been hereditary occupied formal position in the village. The presence of a successful former Korean TKI became a balancing force among the landlord groups who among themselves were also splited.

Basically, the upper classes in Jongso can be divided into two: economically upper class and socially. Those who are economically upper class are successful former Korean migrant workers, pioneers's descendants and petinggen. They are recognized as the upper class because of the more economical asset ownership than the average community. Meanwhile, those who belong to the social class are kiai / religious leaders/madrasah teachers and government officials. Kiai/religious leaders/madrasah teachers are recognized as upper class because they are considered knowledgeful, although generally they come from lower middle class. Meanwhile, civil servants are socially inclusive of the upper classes and (respected) because they are capable of solving the constraints faced in society and bridging the community to settle matters pertaining to the bureaucracy as Mundi (agriculture adviser, 46 y.o) mentioned: "When I work in private, my parents in-law were undemined me. When I wear this uniform, the treatment was different, very different, though materially far below than in private".bThe social restratification in Jongso is morethicker in the shift in 
upper-class positions due to the structure of income and not by structure of education and work, as can be seen in Figure 4.

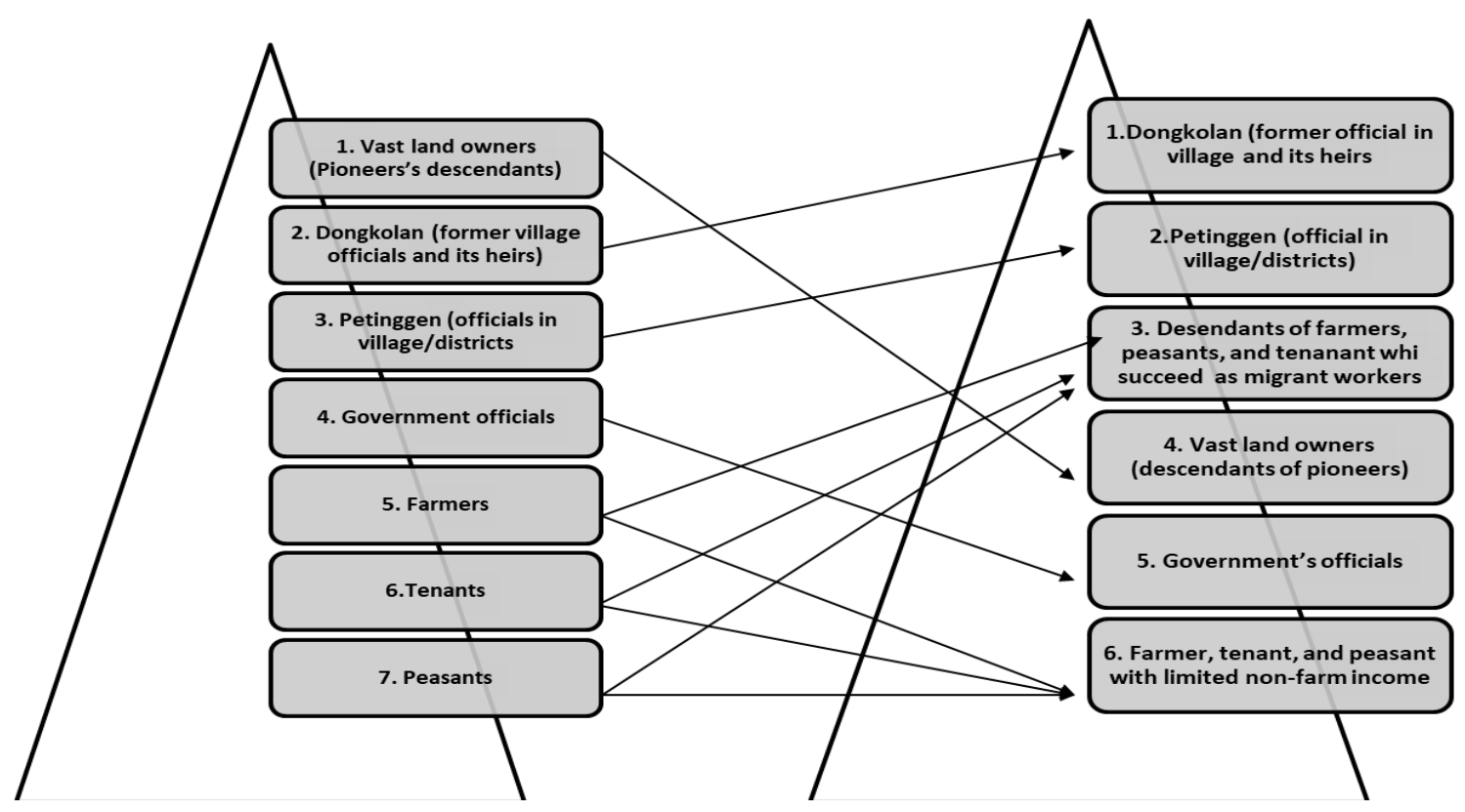

Figure 4 - Restratification within rice peasants community in Jongso

Successful peasants and tenant heirs on experiencing upward social mobility become higher strata of the pioneer's descendants is driven by income structure. Nevertheless they remain under the petinggen and the dongkolan from community's respect perspective. The income structure of migrant workers is the highest among other non-agricultural jobs in Jongso. Currently, income that is close to the income of Korean migrant workers is only revenue for investors or owners of stalls. Meanwhile, pioneers descendants or landlords, are experiencing downward mobility from the side of the income structure. Some of them are experiencing difficulties because various need to keep their upper class identity, which often costly,for instance the ceremonies of death. In addition to the cost of maintaining upper class identity, the declining mobility trends also occur due to investments in substantial education conducted by the upper classes. This often makes them sell the land they own. In general, those who send their children to college level are from the wealthy (landlord) family. College graduates will be oriented to become employees both in government and private environment.

In the context of restratification, what appears to be called by Halamska (2011) as a transitional group is quasi-peasants, educated unemployed and migrants. Transitional groups are not all found in Jongso. There are only two transitional groups of pseudopeasants and migrants. Quasi-peasants are the vast majority of those who ultimately go into business and put agriculture as a side job with less desirable results. These average peasants are those who currently work as owners of stall, stall labor, and workers in the Kudus cigarette factory. Their income is much greater than the work on the farm. 'Stall labors' and workers in the factory in average are peasant with a land less than 0.25 hectares or even landless. They do not expect much from farmland because of the risk of high crop failure. Educated unemployment is not found in Jongso, as the number of relatively few college graduates tends to be directly absorbed in the private or government sectors. Usually they use social networks or acquaintances to facilitate their children's access to the job.

\section{CONCLUSION}

The decline of agricultural dominance in the rural economic structure has led to changes in social structure. The hierarchy of prosperity in the rural has also changed. To 
improve living standards, communities have an increasingly diverse their sources of income. Substantive increase in revenue. Restratification has occurred since the rural population has not depend on agriculture. Restratification occurs because of changes in the structure of work, the structure of education and the structure of income. The categories of work relating to agriculture are diminishing as the category of non-agricultural employment is increasingly diverse.

Economic diversification has created a new rurality. Type of rural (new rurality) is characterized by increasing prosperity, a highly developed infrastructure, more practical lifestyles, more open interactions, diverse economic activities, and agriculture which is no longer as the dominant source of income. Diversification opens opportunities for vertical social mobility for the rural poors, the children of farm laborers and tenants who then choose to become migrant workers abroad (Korea). There has been a restratification characterized by the emergence of migrant groups as a new social class that shifts the upper class position originally occupied by landlords and their descendants. Migrants become the transitional group that occupies the upper class position. They are a new upper class in social stratification in the rural that manages to show its prosperity through the accumulation of capital from remittances they bring back to the village.

\section{REFERENCES}

1. Berg, BL. 2001. Qualitative Research Methods for the Social Sciences. USA: Allyn \& Bacon.

2. Bryceson, D. 1996. Deagrarianization and Rural Employment in Sub-Saharan Africa: A Sectoral Perspective. World Development, 24(1), 97111.

3. Bryceson, D. 2002. The Scramble in Africa: Reorienting Rural Livelihoods. World Development, 30 (5), 725739.

4. Chase, J. 2010. The Place of Pluriactivity in Brazil's Agrarian Reform Institutions. Journal of Rural Studies (26), 8593.

5. Connor,T. and Mtwana, N. 2017. Vestige Garden Production and deagrarianization in Three Villages in the Eastern Cape, South Africa. South African Geographical Journal. Issue 1, March, 122.

6. Creswell, JW. 2003. Research Design: Qualitative, Quantitative and Mixed Method Approaches. USA: Sage Publication.

7. Ducrotoy, MJ; Revie, CW; Shaw, AP; Musa, UB; Bertu, WJ; Gusi, AM; Ocholi, RA; Majekodunmi, AO; and Welburn, SC. 2017. Wealth, Household Heterogenity and Livelihood Diversification of Fulani Pastoralist in the Kachia Grazing Reserve, Northern Nigeria during a Period of Social Transition. PLOS ONE 12 (3). 122.

8. Ebenezer, M and Abbyssinia, M. 2018. Livelihood Diversification and Its Effect on Household Poverty in Eastern Cape Province, South Africa. The Journal of Developing Areas, 52 (1) 235249.

9. Halamska, M. 2011. The Polish Rural in the Process of Transformation 1989-2009. Polish Sociological Review I (173), 3554.

10. Hebinck, P; Mtati, N; Shackleton, C. 2018. More than just fields: Reframing deagrarianisation in landscapes and livelihoods. Journal of Rural Studies, 61 323-334.

11. Kaitlin, Y., and Marie, P. 2010. Migration, Development and a New Rurality in the Valle Alto, Bolivia. (1), 107124.

12. Khan, W et al. 2017. Can Diversification of Livelihood Increase Income of Farm Households? A Case Study in Uttar Pradesh. Agricultural Economics Research Review. $30,2734$.

13. Meert, $\mathrm{H}$ et al. 2005. Farm Household Survival Strategies and Diversification on Marginal Farms. Journal of Rural Studies 21, 8197.

14. Pritchard, B; Vicol,M; Jones R. 2017. How does the Ownership of Land Affect Household Livelihood Patways Under Conditions of Deagrainization? Hangin in, Stepping up and stepping out in two North Indian Villages. Singapore Journal of Tropical Geography, 38 41-57. 
15. Shackleton, R., Shackleton, C., Shackleton, S., Gambiza, J. 2018. Deagrarianisation and Forest Revegetation in a Biodiversity Hotspot on the Wild Coast, South Africa. Plos One, 8(10) 112.

16. Steward, A. 2007. Nobody Farms Here Anymore: Livelihood Diversification in the Amazonian Community of Carvao, a Historical Perspective. Agriculture and Human Values, 24, 7592.

17. Terano, R and Fujimoto, A. 2009. Employment Structure in a Rice Farming Village in Malaysia: A Case Study in Sebrang Prai. J ISSAAS. 15 (2), 81-92.

18. Yaro, JA. 2006. Is Deagrarianisation Real? A Study of Livelihood Activities in Rural Northern Ghana. The Journal of Modern African Studies, 44 (1), 125156.

19. Yin, Rk. 2003. Case Study Research Design and Methods. Third Edition. USA: Sage Publications. 